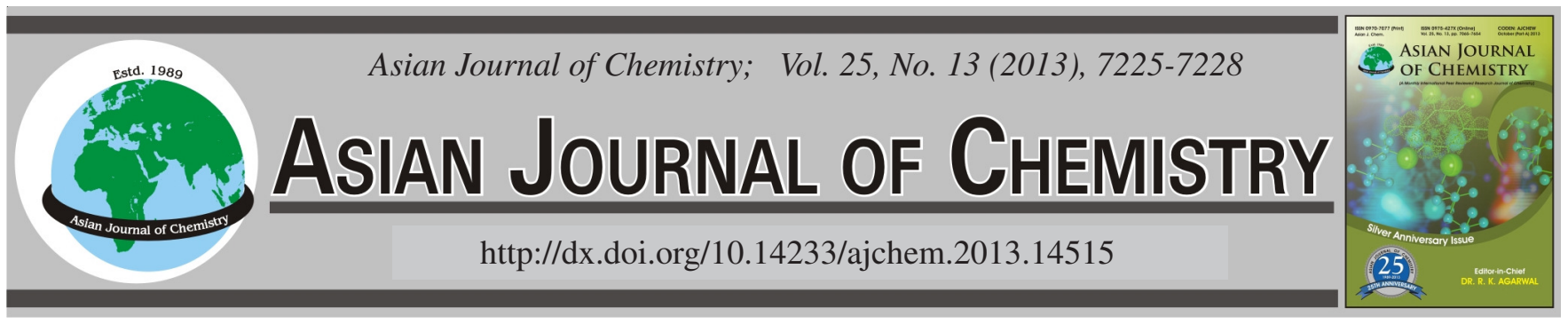

\title{
Thermodynamics of Ion Association of $s$-Acetylthiocholine Halides and Perchlorate in Acetonitrile
}

Nasr H. El-Hammamy ${ }^{1, *}$, Marwa N. El-Hammamy ${ }^{2}$, Nabila M. El-Mallah ${ }^{1}$, Aida I. Kawana ${ }^{3}$ and Heba M. Moharem ${ }^{1}$

${ }^{1}$ Department of Chemistry, Faculty of Science, Alexandria University, P.O. 426, Ibrahimia, Alexandria 21321, Egypt

${ }^{2}$ Department of Physics, Faculty of Science, Damanhour University, Damanhour, Egypt

${ }^{3}$ Department of Chemistry, Faculty of Education, Alexandria University, P.O. 426, Ibrahimia, Alexandria 21321, Egypt

*Corresponding author: E-mail: nasrelhammamy@yahoo.com

(Received: 3 September 2012;

Accepted: 19 June 2013)

AJC-13678

\begin{abstract}
Thermodynamic parameters $\left(\Delta \mathrm{H}^{\mathrm{o}}, \Delta \mathrm{G}^{\mathrm{o}}, \Delta \mathrm{S}^{\circ}\right)$ and the activation energy $(\Delta \mathrm{Es})$ were calculated to explain the limiting equivalent conductance $\left(\Lambda_{0}\right)$ and ion association constant $\left(\mathrm{K}_{\mathrm{A}}\right)$ of $s$-acetylthiocholine halides and perchlorate in acetonitrile at different temperatures by using conductance measurements. It has been evaluated by using Fuoss-Onsager equation. It is evident that the values of $\left(\Lambda_{0}\right)$ increase regularly with increase in temperature. For all salts of $s$-acetylthiocholine, $\left(\Lambda_{0}\right)$ indicates less solvation or higher mobility of the ions in all solvent systems studied. The free energy change $\Delta \mathrm{G}^{\mathrm{o}}$ values are negative for all salts $\left(\mathrm{Br}^{-}, \mathrm{I}^{-}\right.$and $\left.\mathrm{ClO}_{4}^{-}\right)$. Clearly strengthening to interionic association at higher temperatures is largely caused by a decrease in the permitivity of the solvent. The positive values of $\left(\Delta \mathrm{H}^{\circ}\right)$ for three salts $\left(\mathrm{Br}^{-}, \mathrm{I}^{-}\right.$and $\left.\mathrm{ClO}_{4}^{-}\right)$show that the association processes are endothermic in nature. Entropy change $\left(\Delta \mathrm{S}^{\circ}\right)$ values are positive for all salts indicate the randomness of ions in all solvent systems studied.
\end{abstract}

Key Words: $s$-Acetylthiocholine salts, Limiting equivalent conductance, Ion association, Activation energy, Acetonitrile.

ᄂ _ - - - - - - - - - - - - - - - - - - - - - - - - - - - - -

\section{INTRODUCTION}

Acetonitrile has increased with opens up broad possibilities for studying biological objects ${ }^{1}$ and for analytical practice $^{2}$. The selection of acetonitrile was caused by its high dissolving ability and weak solvation of cation in it. A quantitative description of $s$-acetylthiocholine halides and perchlorate with participation of cation cannot be performed without taking into account ionic association between the cation and anion of salt under study. This is in part explained by the absence of reliable data on inter-ionic association constants for salts in non-aqueous solvents a wide temperature range.

The purpose of this work was to study interionic association in solutions of $s$-acetylthiocholine halides and perchlorate in acetonitrile at various temperatures. We also determined the acetonitrile of solvation effect to the energy characteristics of inter-ionic interactions. The conductometric method, allowed us to determine not only inter-ionic association constants but also the limiting conductivities of single ions ${ }^{3,4}$, which gave additional information about the dynamics of ion-molecular interaction $^{5}$. To study the influence of the nature of the anions on ionic association and solvation, we selected salts containing common cation and different anions but substantially different in electronic structures ${ }^{6}$.
Fuoss and Onsager ${ }^{7}$, used the sphere in continuum model and gave the following 3-parameter equation for the 1:1 associated electrolyte.

$$
\Lambda=\Lambda_{\circ}-\mathrm{S}(\mathrm{C} \gamma)^{1 / 2}+\mathrm{EC} \gamma \log \mathrm{C} \gamma+\left(\mathrm{J}-\mathrm{B} \Lambda_{\circ}\right) \mathrm{C} \gamma-\mathrm{K}_{\mathrm{A}} \mathrm{C} \gamma \Lambda \mathrm{f}^{2}
$$

where, $\Lambda$ is the equivalent conductance ohm ${ }^{-1}$ equiv ${ }^{-1} \mathrm{~cm}^{2}$, $\mathrm{C}$ is the concentration (equiv/L) and $\gamma$ is the degree of dissociation which can be calculated using the following equation:

$$
\gamma=\Lambda /\left[\Lambda_{0}-\mathrm{S}\left(\mathrm{C} \Lambda / \Lambda_{0}\right)^{1 / 2}\right]
$$

$\mathrm{S}$ and $\mathrm{E}$ being the theoretically predicted constants, which depend on the dielectric constant $D$, the viscosity $\eta$ and the absolute temperature $\mathrm{T}$ of the medium. $\mathrm{J}$ is a term which includes the ion and ion-solvent interactions and is given by the equation

$$
\mathrm{J}=\sigma_{1} \Lambda_{\circ}+\sigma_{2}
$$

where $\sigma_{1}$ and $\sigma_{2}$ are functions of the closest distance of approach $\mathrm{a}^{\mathrm{o}}$ in addition to $\eta$ and $\mathrm{D}$.

\section{EXPERIMENTAL}

The $s$-acetylthiocholine bromide, iodide and perchlorate were purified as reported in the literature ${ }^{8}$, acetonitrile (BDH) was purified as reported earlier ${ }^{9}$. The specific conductance for purified acetonitrile at different temperatures $(25,30,35$ and 
$\left.40{ }^{\circ} \mathrm{C}\right)$ was found to be $(5-7) \times 10^{-8} \Omega^{-1} \mathrm{~cm}^{-1}$. All solutions were reported by reducing weight to vacuo. Salts were weighed on microbalance which reads to $\pm 0.1 \mathrm{mg}$. Dilution was carried out successively into the cell by siphoning the solvent by means of weighing pipette. Conductivity Bridge was model Crison Cl P31 and the cell with bright platinum electrodes was used. The cell constant was $0.1 \mathrm{~cm}^{-1}$ for dilute solutions. The solvent constants used in all calculations were taken as reported ${ }^{10-13}$, i.e., densities $\left(\mathrm{d}_{25^{\circ}}\right)=0.7762 \mathrm{~g} \mathrm{~cm}^{-3},\left(\mathrm{~d}_{30^{\circ}}\right)=0.7712 \mathrm{~g} \mathrm{~cm}^{-3}$, $\left(\mathrm{d}_{35^{\circ}}\right)=0.7652 \mathrm{~g} \mathrm{~cm}^{-3},\left(\mathrm{~d}_{40^{\circ}}\right)=0.7492 \mathrm{~g} \mathrm{~cm}^{-3}$, respectively, the viscosities $\left(\eta_{25^{\circ}}\right)=0.3412 \times 10^{-2} \mathrm{P},\left(\eta_{30^{\circ}}\right)=0.3270 \times 10^{-2} \mathrm{P}$ and $\left(\eta_{35^{\circ}}\right)=0.31309 \times 10^{-2} \mathrm{P},\left(\eta_{40^{\circ}}\right)=0.2995 \times 10^{-2} \mathrm{P}$, respectively and the dielectric constants $\left(\mathrm{D}_{25^{\circ}}\right)=36.61,\left(\mathrm{D}_{30^{\circ}}\right)=35.97,\left(\mathrm{D}_{35^{\circ}}\right)$ $=35.36,\left(\mathrm{D}_{40^{\circ}}\right)=34.74$, respectively.

\section{RESULTS AND DISCUSSION}

It is evident from the Tables 1-3 that the values of $\Lambda_{0}$ increase regularly with increase in temperature for salts of $s$ acetylthiocholine bromide, iodide and perchlorate, indicating less solvation or higher mobility of the ions in all solvent systems studied. This is due to the fact that the increased thermal energy results in greater bond breaking and also variation in vibrational, rotational. Also translational energy of molecules leads to higher frequency and higher mobility of ions ${ }^{14}$. Also, it is clear that the association constant $\left(\mathrm{K}_{\mathrm{A}}\right)$ values increase with increase in temperature due to decreasing in dielectric constant of the medium ${ }^{1}$.

Since the conductance measurements of an ion depend on its mobility, it is quite reasonable ${ }^{15}$ to treat the conductance data similar to the one that employed for the processes taking place with change of temperature, i.e.

$$
\begin{gathered}
\Lambda_{0}=\mathrm{Ae}^{-\Delta \mathrm{Es} / \mathrm{RT}} \\
\text { or } \quad \log \Lambda_{0}=\log \mathrm{A}-\left(\frac{\Delta \mathrm{Es}}{2.303 \mathrm{RT}}\right)
\end{gathered}
$$

where $\mathrm{A}$ is the frequency factor, $\mathrm{R}$ is the ideal gas constant and $\Delta \mathrm{Es}$ is the Arrhenius activation energy of transport processes. The $\Delta$ Es values have been computed from the slope (- $\Delta \mathrm{Es} / 2.303 \mathrm{RT})$ of the plot of $\log \Lambda_{0}$ versus $1 / \mathrm{T}$ and recorded in Tables 1-3 (Fig. 1). From the tables, the activation energy is positive value for three salts in all solvents. Its values were decreased from $\mathrm{Br}^{-}$to $\mathrm{I}^{-}$and increased from $\mathrm{I}^{-}$to $\mathrm{ClO}_{4}^{-}$, indicates that higher mobility of the ions in solution and hence higher $\Lambda_{0}$ values. The free energy change $\Delta \mathrm{G}^{\mathrm{o}}$ for the association process is calculated from eqn. $2^{16}$

$$
\Delta \mathrm{G}^{\mathrm{o}}=-\mathrm{RT} \ln \mathrm{K}_{\mathrm{A}}
$$

Also it is evident From Tables 1-3, that the free energy change $\left(\Delta \mathrm{G}^{\circ}\right)$ values are negative for three salts $\left(\mathrm{Br}^{-}, \mathrm{I}^{-}\right.$and
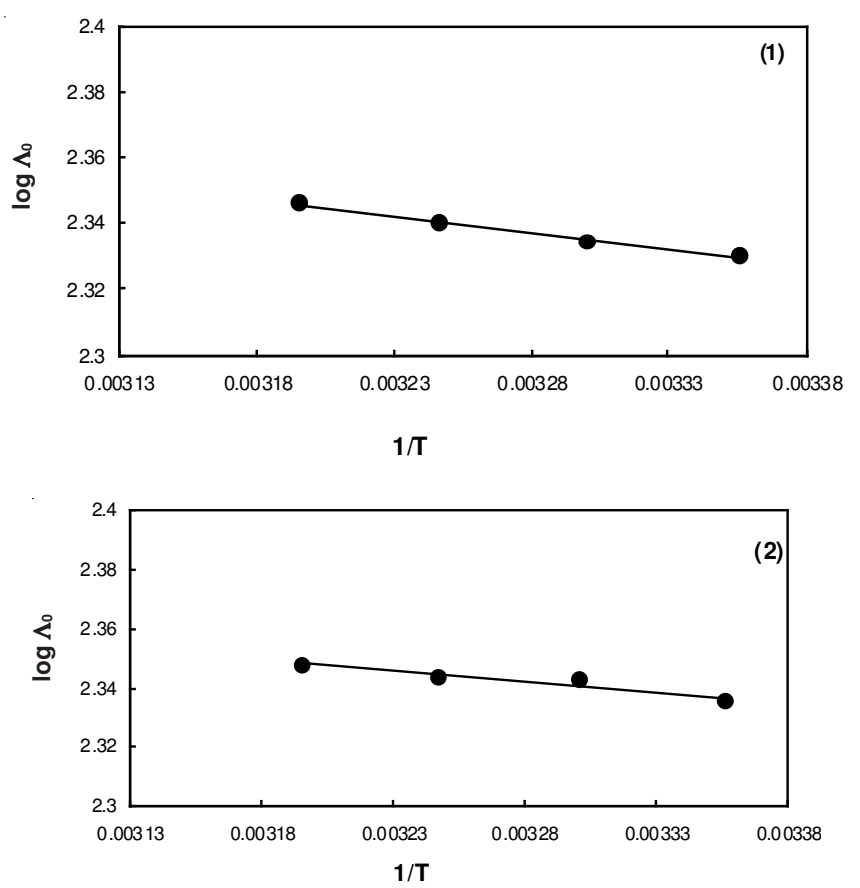

\begin{tabular}{|c|c|c|c|c|c|c|}
\hline $\mathrm{T}(\mathrm{K})$ & $\Lambda_{0}^{9-12}\left(\mathrm{ohm}^{-1}\right.$ equiv $\left.{ }^{-1} \mathrm{~cm}^{2}\right)$ & $\mathrm{K}_{\mathrm{A}}^{9-12}$ & $\Delta \mathrm{E}_{\mathrm{s}}^{\mathrm{o}}\left(\mathrm{kJ} \mathrm{mol}^{-1}\right)$ & $\Delta \mathrm{H}^{\mathrm{o}}\left(\mathrm{kJ} \mathrm{mol}^{-1}\right)$ & $\Delta \mathrm{G}^{\mathrm{o}}\left(\mathrm{kJ} \mathrm{mol}^{-1}\right)$ & $\Delta \mathrm{S}^{\mathrm{o}}\left(\mathrm{J} \mathrm{mol}^{-1} \mathrm{~K}^{-1}\right)$ \\
\hline 298 & 214.01 & - & & & - & - \\
\hline 303 & 216.08 & - & 1.839 & 82.283 & - & - \\
\hline 308 & 218.72 & 109.0 & & & -12.015 & 306.16 \\
\hline 313 & 221.98 & 182.1 & & & -13.546 & 306.16 \\
\hline
\end{tabular}

TABLE-1

THERMODYNAMIC PARAMETERS OF $s$-ACETYLTHIOCHOLINE BROMIDE IN ACETONITRILE AT DIFFERENT TEMPERATURES

TABLE-2

\begin{tabular}{|c|c|c|c|c|c|c|}
\hline \multicolumn{7}{|c|}{$\begin{array}{c}\text { TABLE-3 } \\
\text { THERMODYNAMIC PARAMETERS OF } s \text {-ACETYLTHIOCHOLINE } \\
\text { PERCHLORATE IN ACETONITRILE AT DIFFERENT TEMPERATURES }\end{array}$} \\
\hline $\mathrm{T}(\mathrm{K})$ & $\Lambda_{0}^{9-12}\left(\mathrm{ohm}^{-1}\right.$ equiv $\left.^{-1} \mathrm{~cm}^{2}\right)$ & $\mathrm{K}_{\mathrm{A}}{ }^{9-12}$ & $\Delta \mathrm{E}_{\mathrm{s}}^{\mathrm{o}}\left(\mathrm{kJ} \mathrm{mol}^{-1}\right)$ & $\Delta \mathrm{H}^{\circ}\left(\mathrm{kJ} \mathrm{mol}^{-1}\right)$ & $\Delta \mathrm{G}^{\mathrm{o}}\left(\mathrm{kJ} \mathrm{mol}^{-1}\right)$ & $\Delta \mathrm{S}^{\mathrm{o}}\left(\mathrm{J} \mathrm{mol}^{-1} \mathrm{~K}^{-1}\right)$ \\
\hline 298 & 216.83 & 19.16 & \multirow{4}{*}{1.84} & \multirow{4}{*}{144.09} & -7.32 & 508.08 \\
\hline 303 & 221.28 & 118.83 & & & -12.034 & 515.28 \\
\hline 308 & 223.29 & - & & & - & - \\
\hline 313 & 224.86 & 365.90 & & & -15.36 & 509.44 \\
\hline
\end{tabular}

THERMODYNAMIC PARAMETERS OF $s$-ACETYLTHIOCHOLINE IODIDE IN ACETONITRILE AT DIFFERENT TEMPERATURES

\begin{tabular}{ccccccc}
\hline $\mathrm{T}(\mathrm{K})$ & $\Lambda_{0}^{9-12}\left(\mathrm{ohm}^{-1}\right.$ equiv $\left.^{-1} \mathrm{~cm}^{2}\right)$ & $\mathrm{K}_{\mathrm{A}}{ }^{9-12}$ & $\Delta \mathrm{E}_{\mathrm{s}}^{\mathrm{o}}\left(\mathrm{kJ} \mathrm{mol}^{-1}\right)$ & $\Delta \mathrm{H}^{\circ}\left(\mathrm{kJ} \mathrm{mol}^{-1}\right)$ & $\Delta \mathrm{G}^{\mathrm{o}}\left(\mathrm{kJ} \mathrm{mol}^{-1}\right)$ & $\Delta \mathrm{S}^{\circ}\left(\mathrm{J} \mathrm{mol}^{-1} \mathrm{~K}^{-1}\right)$ \\
\hline 298 & 216.44 & 83.304 & & & -10.96 & 444.80 \\
303 & 220.17 & 216.06 & 1.39 & 121.59 & -13.54 & 445.99 \\
308 & 220.84 & 409.13 & & & -15.40 & 444.79 \\
313 & 222.77 & - & & & - & - \\
\hline
\end{tabular}




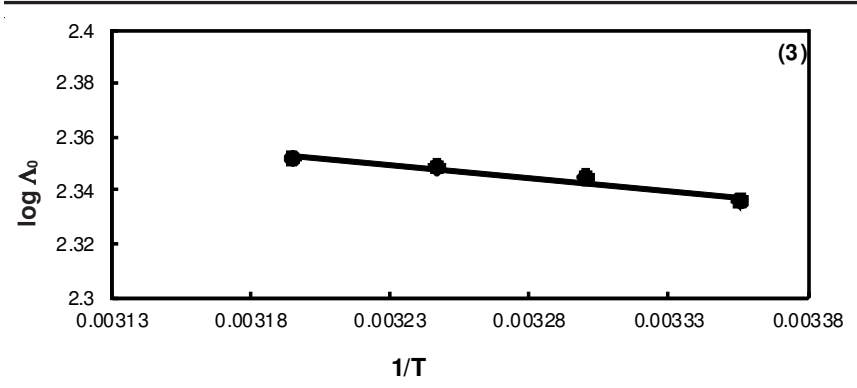

Fig. 1. Variation of $\log \Lambda_{0}$ versus $1 / \mathrm{T}$ for $s$-acetylthiocholine (1) bromide, (2) iodide and (3) perchlorate in acetonitrile at different temperatures

$\mathrm{ClO}_{4}^{-}$) in all solvent systems studied. This means that the association process is favoured over the dissociation process in all solvent systems. The negativity of $\left(\Delta \mathrm{G}^{\circ}\right)$ increased with increases the ion association as the temperature grows to $40^{\circ} \mathrm{C}$ for all salts contain the anions $\left(\mathrm{Br}^{-}, \mathrm{I}^{-}\right.$and $\left.\mathrm{ClO}_{4}^{-}\right)$. Clearly, strenghthening to interionic association at higher temperatures is largely caused by a decrease in the permittivity of the solvent ${ }^{1}$.

The enthalpy change (heat of association) $\left(\Delta \mathrm{H}^{\circ}\right)$ is obtained from the plot of $\log \mathrm{K}_{\mathrm{A}}$ versus $1 / \mathrm{T}$ (Fig. 2) according to the following equation:
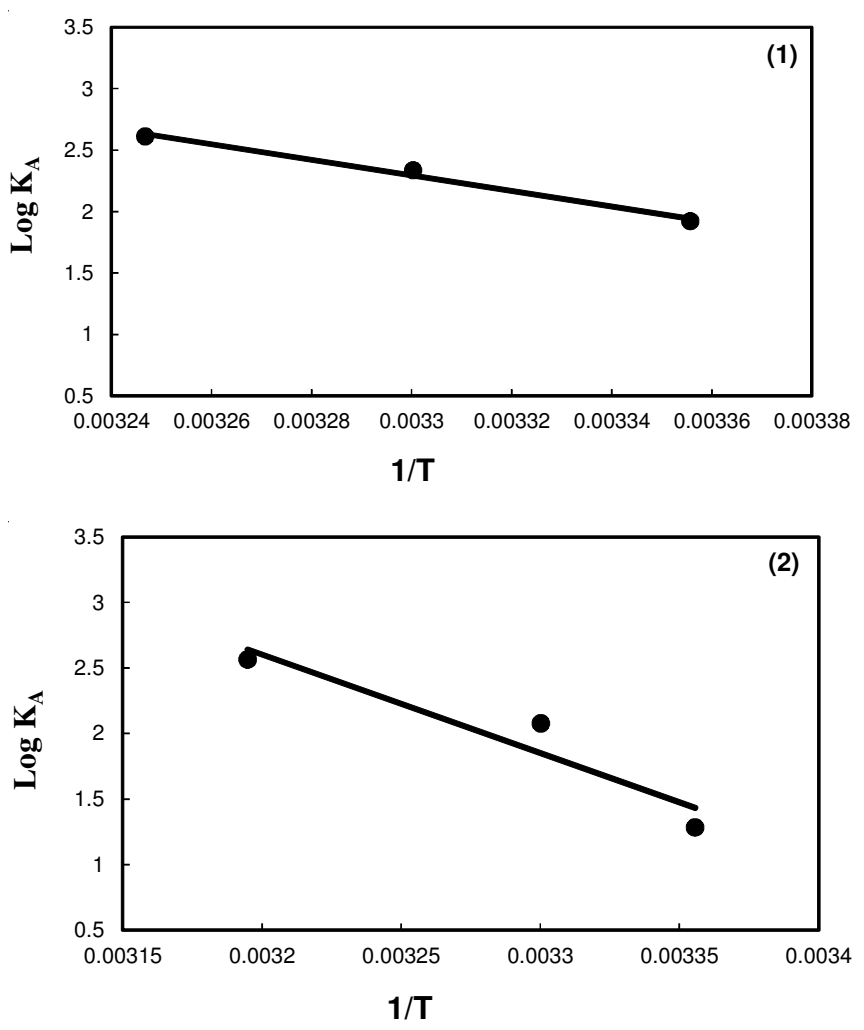

Fig. 2. Variation of $\log \mathrm{K}_{\mathrm{A}}$ versus $1 / \mathrm{T}$ for $s$-acetylthiocholine (1) iodide and (2) perchlorate in acetonitrile at different temperatures

$$
\log \frac{\mathrm{K}_{2}}{\mathrm{~K}_{1}}=\frac{\Delta \mathrm{H}^{\mathrm{o}}}{2.303 \mathrm{R}}\left(\frac{\mathrm{T}_{2}-\mathrm{T}_{1}}{\mathrm{~T}_{1} \mathrm{~T}_{2}}\right)
$$

where $K_{2}$ is association constant at high temperature $T_{2}$ and $\mathrm{K}_{1}$ is association constant at lower temperature $\mathrm{T}_{1} . \mathrm{K}_{\mathrm{A}}$ values of bromide at $25,30{ }^{\circ} \mathrm{C}$ are irregular values, so we cannot use these values in calculations. The values of $\left(\Delta \mathrm{H}^{\circ}\right)$ were calculated, where the slope equal $\left(-\Delta \mathrm{H}^{\circ} / 2.303 \mathrm{R}\right)$. The positive values of $\Delta \mathrm{H}^{\circ}$ for three salts $\left(\mathrm{Br}^{-}, \mathrm{I}^{-}\right.$and $\left.\mathrm{ClO}_{4}^{-}\right)$show that the association processes are endothermic in nature and the calculated entropy change $\left(\Delta \mathrm{S}^{\circ}\right)$, from Gibbs-Helmholtz equation;

$$
\Delta \mathrm{G}^{\mathrm{o}}=\Delta \mathrm{H}^{\mathrm{o}}-\mathrm{T} \Delta \mathrm{S}^{\mathrm{o}}
$$

The positive values of $\left(\Delta \mathrm{S}^{\circ}\right)$ for three salts $\left(\mathrm{Br}^{-}, \mathrm{I}^{-}\right.$and $\left.\mathrm{ClO}_{4}^{-}\right)$indicates the randomness of ions in all solvent systems studied. The values of $\Delta \mathrm{H}^{\circ}, \Delta \mathrm{G}^{\mathrm{o}}$ and $\Delta \mathrm{S}^{\circ}$ are recorded in Tables 1-3 for $s$-acetylthiocholine bromide, iodide and perchlorate in acetonitrile at different temperatures $\left(25,30,35\right.$ and $\left.40{ }^{\circ} \mathrm{C}\right)$. $\Delta \mathrm{G}^{\mathrm{o}}$ values decrease with increase in temperature. The values of $\left(\Delta \mathrm{G}^{\circ}\right)$ are negative for three salts in the solvent systems studied. These values decrease to more negative values at increasing temperature favours the transfer of the released solvent molecules into bulk solvent and leads to a smaller $\left(\Delta \mathrm{G}^{\circ}\right)$ values ${ }^{17}$. It was observed that the $\Delta \mathrm{H}$ values increase in order: $\mathrm{ClO}_{4}^{-}>\mathrm{I}^{-}>\mathrm{Br}^{-}$. The $\left(\Delta \mathrm{H}^{\circ}\right)$ values were found to be positive in all salts (bromide, iodide and perchlorate) of $s$-acetylthiocholine in acetonitrile. Positive and high $\left(\Delta \mathrm{H}^{\circ}\right)$ values can be attributed to the interaction between ions ${ }^{18}$. As presented in Tables $\left(\Delta S^{\circ}\right)$ values were positive for all salts in acetonitrile at different temperatures used in the study because of decrease in the solvation of ion-pair compared to that of the free ions ${ }^{19-21}$. This may be attributed to increase in the degree of freedom upon association, mainly due to the release of solvent molecules.

In other words, the solvation of ions becomes weak as soon as the ion-pairs formation occurs ${ }^{15}$. The main factors which govern the standard entropy of ion association of electrolytes are (i) the size and shape of ions, (ii) charge density on ions, (iii) electrostriction of the solvent molecules around the ions and (iv) the penetration of the solvent molecules inside the space of ions ${ }^{22}$.

Bag et al..$^{23}$, measured the conductance of $\mathrm{Co}$ (III) complex monochloride in $\mathrm{MeOH}-\mathrm{H}_{2} \mathrm{O}$ mixtures at different temperatures $\left(25,30,35\right.$ and $\left.40^{\circ} \mathrm{C}\right)$. It was found that, at a particular temperature $\Delta \mathrm{G}^{\mathrm{o}}$ becomes more negative with increase in temperature. This indicates that ion-pair association is favoured with lowering of dielectric constant of medium. A positive entropy change is explained on the assumption that iceberg structure around the cation is broken when association takes place leading to an increase in the degree of disorderless ${ }^{24}$.

Dash et al. ${ }^{14}$, measured the conductance of $\mathrm{Co}(\mathrm{III})$ complex of chloride and bromide in different composition of $\mathrm{H}_{2} \mathrm{O}-\mathrm{MeOH}, \mathrm{H}_{2} \mathrm{O}$-EtOH and $\mathrm{H}_{2} \mathrm{O}-n$ - $\mathrm{PrOH}$ at different temperatures. It was found that the association constant $\mathrm{K}_{\mathrm{A}}$ values of $\mathrm{Co}$ (III) complexes of chloride and bromide increase with increase in temperature. It is evident that the activation energy $\mathrm{E}_{\mathrm{s}}$ is positive for both $\mathrm{K}_{\mathrm{A}}$ in all solvents and free energy change $\Delta \mathrm{G}^{\mathrm{o}}$ values are negative for both association constants in solvent with increase the temperature. This indicates that the association process is favoured over dissociation process in all solvent systems. The positive values of $\Delta \mathrm{H}^{\mathrm{o}}$ for both complexes show that the association processes are endothermic in nature. The positive value of $\Delta \mathrm{S}^{\circ}$ indicates the randomness of ions in solvent system studied.

El-Hammamy et al..$^{25}$, measured the conductance of 1:1 $s$-acetylthiocholine salts $\left(\mathrm{Cl}^{-}, \mathrm{Br}^{-}, \mathrm{I}^{-}\right.$and $\left.\mathrm{ClO}_{4}^{-}\right)$in water at different temperatures $\left(25,30,35^{\circ} \mathrm{C}\right)$ were analyzes using Fuoss-Onsager equation, it obtained the values of $\Lambda_{0}, \mathrm{~K}_{\mathrm{A}}$ and 
$\mathrm{a}^{\mathrm{o}}$ (solvation). It was found that $\Lambda_{0}$ and $\mathrm{a}^{\mathrm{o}}$ increase with increase the temperature while $\mathrm{K}_{\mathrm{A}}$ decrease with increasing the temperatures for all salts of $s$-acetylthiocholine according to electrostatic attraction theory. Thus from the plot of $\log \Lambda_{0}$ versus $1 / \mathrm{T}$ for $s$-acetylthiocholine halides and perchlorate in water at different temperatures, $\Delta \mathrm{E}_{\mathrm{s}}$ values have been evaluated, also $\Delta \mathrm{H}^{\mathrm{o}}, \Delta \mathrm{G}^{\mathrm{o}}$ and $\Delta \mathrm{S}^{\mathrm{o}}$ for salts. It was found that negative values of $\Delta \mathrm{H}^{\mathrm{o}}, \Delta \mathrm{G}^{\mathrm{o}}$ and $\Delta \mathrm{S}^{\mathrm{o}}$ in water at different temperatures; negative value of $\Delta \mathrm{H}^{\circ}$ indicated that ion association processes were exothermic in nature in all solvents at all temperatures. The solvated radii were also increased with temperature indicating a higher solvation process due to increase in the electronic clouds around the solvated molecules as a result of an increase in their vibration and rotational motion. The limiting equivalent conductance and dissociation degree were also increased as the temperature increased, indicating higher solvation process ${ }^{26}$. The negative values of different thermodynamic parameters $\Delta \mathrm{H}^{\mathrm{o}}, \Delta \mathrm{G}^{\mathrm{o}}$ and $\Delta \mathrm{S}^{\mathrm{o}}$, for all salts under test in the used solvent, indicated exothermic association process was less energy-consuming and more stabilized ${ }^{27}$.

El-Hammamy et al. ${ }^{17}$, measured the conductance of $1: 1$ acetylthiocholine salts $\left(\mathrm{Br}^{-}, \mathrm{I}^{-}\right.$and $\left.\mathrm{ClO}_{4}^{-}\right)$in methanol at different temperatures $\left(25,30,35,40{ }^{\circ} \mathrm{C}\right)$ were analyzes using Fuoss-Onsager equation, it obtained the values of $\Lambda_{0}, K_{\mathrm{A}}$ and $\mathrm{a}^{\mathrm{o}}$ (solvation). It was found that $\Lambda_{0}$ and $\mathrm{K}_{\mathrm{A}}$ increase with increase the temperature. Thus from the plot of $\log \Lambda_{0}$ versus $1 / \mathrm{T}$ for $s$-acetylthiocholine chloride, bromide and perchlorate in methanol at different temperatures, $\Delta \mathrm{E}_{\mathrm{s}}$ values have been evaluated, also $\Delta \mathrm{H}^{\circ}, \Delta \mathrm{G}^{\circ}$ and $\Delta \mathrm{S}^{\circ}$ for salts. It was found that values of $\Delta \mathrm{G}^{\mathrm{o}}$ are negative for three $\mathrm{K}_{\mathrm{A}}$ constants in solvent with increase the temperature. This indicates that ion association process is favoured over dissociation process in all solvent systems. The positive values of $\Delta \mathrm{G}^{\mathrm{o}}$ are endothermic in nature in three salts. The positive values of $\Delta \mathrm{S}^{\circ}$ are due to the randomness of ions in solvent system studied.

\section{REFERENCES}

1. O.N. Kalugin, V.N. Agieienko, N.A. OtroshKo and V.V. Moroz, Russian J. Phys. Chem. A, 83, 231 (2009).

2. A.D. Roshal, A.V. Grigorovich and A.O. Doroshenko, J. Phys. Chem., 102, 5907 (1998).

3. A. Feofanov, A. Ianoul and S. Gromov, J. Phys. Chem., 101, 4077 (1997).

4. A. Nezhadali, M. Hakimi and A. Naem, Asian J. Chem., 20, 1451 (2008).

5. W. Libus and H. Strzelecki, J. Electrochim. Acta, 15, 703 (1970).

6. W. Libus and H. Strzelecki, J. Electrochim. Acta, 16, 1749 (1971).

7. R.M. Fuoss and L. Onsager, J. Phys. Chem., 61, 668 (1957); R.M. Fuoss, J. Am. Chem. Soc., 81, 2659 (1959).

8. A.I. Kawana, Bull. Electrochem., 16, 225 (2000).

9. N.H. El-Hammamy, A.I. Kawana, Sh.A. El-Shazly and F.F. El-Bardisy, Bull. Electrochem., 10, 307 (1994).

10. N.H. El-Hammamy, A.I. Kawana and H.M. Moharem, Alex. J. Pharm. Sci., 25, 34 (2011).

11. N.H. El-Hammamy, A.I. Kawana, M.N. El-Hammamy and H.M. Moharem, J. Chem. Sci. Res., 2, 292 (2011).

12. N.H. El-Hammamy, M.N. El-Kholy, A.I. Kawana and H.M. Moharem, J. Indian Chem. Soc., 89, 1677 (2012).

13. N.H. El-Hammamy, A.I. Kawana, M.N. El-Hammamy and H.M. Moharem, J. Chem. Pharm. Res., 3, 959 (2011).

14. U.-N. Dash, J.R. Mahapatra and B. Lal, J. Mol. Liq., 124, 13 (2006).

15. S. Glasstone, An Introduction to Electrochemistry, Van Nostrand, New York (1965).

16. J.F. Coetzee and C.D. Ritchie, Solute-Solvent Interaction, MarcelDekker, New York, Vol. 2 (1976).

17. N.H.El-Hammamy, M.N. El-Hammamy, N.M. Al Mallah, A.I. Kawana, and H.M. Moharem, In Communication (2011).

18. S. Pura, J. Mol. Liq., 136, 64 (2007).

19. H. Yokoyama and H. Kon, J. Phys. Chem., 95, 8956 (1991).

20. S. Pura and G. Atun, J. Solut. Chem., 32, 341 (2003).

21. S. Pura and G. Atun, J. Chem. Eng. Data, 47, 1103 (2002).

22. P.J. Victor, P.K. Muhuri, B. Das and D.K. Hazra, J. Phys. Chem., B103, 11227 (1999)

23. G.C. Bag, N.M. Singh and N.R. Singh, J. Indian Chem. Soc., 78, 294 (2001).

24. M.K. De and R.L. Dutta, J. Indian Chem. Soc., 52, 67 (1975).

25. N.H. El-Hammamy, A.I. Kawana, M.M. El-Kholy, M.F. Amira and G.A. Ibrahim, Alex. J. Pharm. Sci., 23, 79 (2009).

26. A.A. Belal and F.I. El-Dossoki, Egypt. J. Chem., 49, 399 (2006).

27. U.-N. Dash and N.N. Pasupalak, Indian J. Chem., 36A, 88 (1997). 